\title{
Kerangka Konseptual Kepuasan Pelanggan terhadap Jasa Transportasi Online Go Ride menggunakan Service Quality
}

\author{
Hawwin Mardhiana ${ }^{1}$, Rizqa Amelia Zunaidi ${ }^{2}$ Ully Asfari $^{3}$ Anfazul F Azizah $^{4}$ \\ ${ }^{1,3,4}$ Sistem Informasi, Fakultas Teknologi Informasi dan Industri, ITTelkom Surabaya \\ ${ }^{2}$ Teknik Industri, Fakultas Teknologi Informasi dan Industri, ITTelkom Surabaya \\ Email: ${ }^{1}$ hawwin@ittelkom-sby.ac.id, ${ }^{2}$ rizqazunaidi@ittelkom-sby.ac.id, ${ }^{3}$ ully.asfari@ittelkom-sby.ac.id, \\ 2anfazul.azizah@ittelkom-sby.ac.id
}

\begin{abstract}
Customer satisfaction in organizations is one of the critical succes factors for developing organizations. To improve the quality of services, an organization must know customer satisfaction with the services provided by the organization. This study aims to present a conceptual framework that is used to analyze factors that affect service quality, customer loyalty and intention to repurchase or reuse online transportation services, GoRide. A conceptual framework proposed to measure Go-Ride customer satisfaction and its impact on customer loyalty and intention to repurchase. Starting from analyzing what is expected and what is felt by customer when the customer use these services with Servqual Method. This conceptual framework allows stakeholders in online transportation Go-Ride to understand customer and measure the quality of services. Conceptual Framework also can be used to set strategy and decision making improve the quality of customer services. In this study the transportation service provider can also divide customers into various categories, so the organization know how to position itself in the future that can be compared to quality of service with the competitors.
\end{abstract}

Keywords : Go-Ride, Servqual, Customer Satisfaction, Servqual, Customer Loyalty, Intention to repurchase

\begin{abstract}
Abstrak. Kepuasan pelanggan dalam organisasi menjadi salah satu faktor utama agar organisasi tersebut dapat berkembang dengan pesat. Untuk meningkatkan kualitas jasa pelayanan sebuah organisasi harus mengetahui kepuasan pelanggan terhadap jasa atau barang yang diberikan. Penelitian ini bertujuan untuk menyajikan kerangka konseptual yang digunakan untuk menganalisis faktor faktor yang mempengaruhi kualitas layanan, loyalitas pelanggan dan keinginan untuk menggunakan kembali jasa transportasi online yaitu Go-Ride. Kerangka konseptual telah diusulkan untuk mengukur kepuasan pelanggan Go-Ride dan dampaknya pada loyalitas pelanggan dan keinginan menggunakan kembali. Hal tersebut dimulai dari menganalisis dari apa yang diharapkan dan apa yang dirasakan pelanggan saat menggunakan layanan tersebut dengan metode Servqual. Kerangka konseptual ini memungkinkan para pemangku kepentingan jasa transportasi online khususnya Go-Ride untuk memahami pelanggan dan mengukur kualitas layanan atau jasa. Selain itu dapat digunakan untuk mengatur strategi dan pengambilan keputusan bagaimana cara meningkatkan kualitas layanan pelanggan khususnya pengguna jasa transportasi online Go-Ride. Dalam hal ini dari pihak penyedia jasa transportasi juga dapat membagi pelanggan dalam berbagai kategori sehingga tau bagaimana memposisikan di masa yang akan datang yang dapat dibandingkan kualitas layanan dengan pesaing penyedia jasa transportasi online tersebut.
\end{abstract}

Kata Kunci: Go-Ride, Kualitas Layanan, Kepuasan Pelanggan, Servqual, Loyalitas pelanggan,

\section{Pendahuluan}

Seiring dengan pertumbuhan teknologi komunikasi yang sangat pesat membuat persaingan di industri atau organisasi semakin ketat. Dalam hal ini banyak pesaing bisnis yang bergerak di bidang yang sama saling berkompetisi. Dalam kompetisi di industri saat ini, salah satu faktor kritis penentu keberhasilan sebuah perusahaan di pasar adalah aktifitas aktifitas yang berorientasi pada pelanggan (Katsikeas et al, 2000 dalam Kharisma, 2015). Kualitas jasa yang berorientasi pada pelanggan sangat 
menunjang keberhasilan industri jasa. Karena hal tersebut keberhasilan kualitas jasa ditentukan pada kepuasan konsumen. Dampak tersebut juga mempengaruhi pertumbuhan industri khususnya di bidang jasa transportasi untuk memenuhi kebutuhan masyarakat dalam menunjang kegiatan sehari hari.

Beraneka ragam jenis bisnis di bidang transportasi khususnya transportasi online, salah satu perusahaan penyedia jasa transportasi yang berkembang saat ini adalah Gojek. Gojek bekerjasama dengan pengendara ojek yang tersebar di beberapa kota di Indonesia dan menjadi salah satu solusi dalam jasa antar jemput, jasa pengiriman barang, jasa antar makanan, cleaning service dan jasa yang lainnya. Kualitas pelayanan dalam bidang jasa merupakan dasar bagi pemasaran jasa karena inti produk yang dipasarkan adalah suatu kinerja yang berkualitas dan kinerjalah yang dibeli oleh pelanggan oleh karena itu kualitas kinerja pelayanan merupakan dasar bagi pemasaran jasa. Kualitas pelayanan jasa pada Gojek sangat berpengaruh terhadap loyalitas pelanggan pada pengguna Gojek dan keinginan kembali untuk menggunakan jasa tersebut (intention to repurchase). Apabila pengguna tidak puas maka loyalitas pelanggan akan menurun dan berdampak pada keluhan pengguna terhadap pelayanan jasa transportasi Gojek.

Tujuan paper ini adalah menyajikan kerangka konseptual dalam menganalisis faktor faktor yang mempengaruhi kualitas layanan, kepuasan layanan, loyalitas pelanggan dan keinginan untuk menggunakan jasa tersebut terhadap salah satu layanan jasa Gojek yaitu Go-Ride. Penelitian ini menggunakan layanan jasa Go Ride karena Go Ride merupakan layanan pertama dan salah satu core bisnis pada Go Jek. Model yang diusulkan nantinya akan digunakan sebagai dasar pengembangan untuk menguji faktor faktor yang mempengaruhi tingkat kepuasan pelanggan, kualitas pelayanan, loyalitas pelanggan dan keinginan untuk menggunakan jasa transportasi Go-Ride, Untuk menghitung hal tersebut maka digunakan metode Fuzzy Service Quality yang nantinya dapat digunakan untuk menentukan strategi yang digunakan untuk meningkatkan kepuasan pelanggan penyedia jasa transportasi tersebut serta untuk mengetahui bagaimana tingkat loyalitas pelanggan setelah menggunakan jasa tersebut.

\section{Tinjauan Pustaka \\ 2.1 Definisi dan Karaktristik Jasa}

Menurut (Kotler dan Keller, 2009) jasa merupakan suatu tindakan atau kinerja yang ditawarkan suatu pihak kepada pihak lain yang dasarnya tidak dapat dilihat dan tidak menghasilkan hak milik terhadap sesuatu. Sedangkan menurut (Johns,1999 dalam Kharisma,2015) Konsep definisi jasa meliputi industri, output atau penawaran dan proses. Dari definisi tersebut jasa dapat didefinisikan sebagai tindakan atau kinerja suatu organisasi yang dasarnya tidak dapat dilihat dan tidak menghasilkan hak milik terhadap sesuatu dan memberikan manfaat.

Sedangkan karakteristik jasa menurut beberapa sumber dalam (Kharisma, 2015) adalah (1)Intangible (tak nyata) artinya tidak dapat dilihat, dirasa, dicium, didengar atau diraba sebelum dibeli dan dikonsumsi, (2) Heterogeneous (beraneka ragam) artinya dalam penyampaian terdapat banyak variasi bentuk, kualitas dan jenis tergantung pada siapa, kapan dan dimana jasa tersebut diproduksi, (3)Inseparable (tak terpisahkan) dimana barang biasanya diproduksi terlebih dahulu kemudian dijual baru dapat dikonsumsi. Sedangkan jasa pada umunnya dijual lebih dulu baru kemudian diproduksi dan dikonsumsi pada waktu dan tempat yang sama. serta (4)Perishability (tidak tahan lama) dimana jasa merupakan komiditas yang tidak tahan lama, tidak dapat disimpan untuk pemakaian ulang diwaktu mendatang, dijual kembali atau dikembalikan (Edgent \& Parkinson, 1993; Zeithhaml \& Bitner, 2003; Debora, 2008 dalam Kharisma, 2015)

\subsection{Kualitas Layanan}

Kualitas layanan adalah suatu tingkat keunggulan yang diharapkan dimana pengendalian atas tingkat keunggulan tersebut bertujuan untuk memenuhi kebutuhan pelanggan. Sedangkan menurut (Tjiptono, 2006) kualitas pelayanan adalah tingkat keunggulan yang diharapkan dan pengendalian atas tingkat keunggulan untuk memenuhi keinginan pelanggan. Menurut (Kotler dan Keller, 2009) terdapat lima indikator pokok kualitas layanan yaitu : (1)Tangible yang didalamnya termasuk penampilan fasilitas fisik, perlengkapan, karyawan dan bahan komunikasi 
(2)Reliable merupakan kemampuan melaksanakan layanan yang dijanjikan secara meyakinkan dan akurat (3)Responsiveness merupakan kesediaan membangtu pelanggan dan memberikan jasa yang cepat (4)Assurance merupakan pengetahuan dan kesopanan karyawan serta kemampuan mereka dalam menumbuhkan rasa percaya dan keyakinan (5)Emphaty merupakan kesediaan memberikan perhatian yang mendalam dan khusus kepada masing masing pelanggan

Menurut (Gronroos, 1990) pelayanan merupakan suatu aktivitas atau serangkaian aktivitas yang bersifat tidak ksat mata atau tidak dapat diraba yang terjadi sebagai akibat adanya interaksi antara konsumen dengan karyawan atau hal hal lain yang dimasudkan untuk memecahkan permasalahan konsumen atau pelanggan.

Berdasarkan penelitian yang dilakukan oleh Parasuraman et.al. dimensi kualitas pelayanan (service quality) yaitu: (1) Reliability, mencakup konsistensi kerja (performance) dan kemampuan untuk dipercaya (dependability). (2) Responsibility, yaitu kemauan dan kesiapan para karyawan dalam memberikan jasa yang dibutuhkan pelanggan (3) Tangibles, bukti langsung dari jasa berupa fisik, peralatan yang digunakan dan reputasi atau jasa. (4) Responsiveness atau daya tangkap yaitu keinginan para karyawan dalam membantu para pelanggan dan memberikan pelayanan dengan tanggap (5) Jaminan (assurance) mencakup pengetahuan, kemamouan, kesopanan dan sifat dapat dipercaya yang dimiliki para staf yang bebas dari risiko dan keragu raguan (6) Empati merupakan kemudahan dalam melakukan hubungan, komunikasi yang baik, perhatian pribadi dan memahami kebutuhan pelanggan.

\subsection{Teknik Pengukuran}

Menurut (Maholtra \& Briks, 2007) proses pengukuran merupakan aktifitas pokok dari tahapan menemukan dimensi variabel penelitian, memutuskan ukuran untuk masing masing dimensi, menentukan tingkat ukuran yang akan digunakan dalam pengukuran serta menguji validitas dan reliabilitas alat ukur.

\subsection{Pengujian Alat Ukur}

Dalam penelitian ini, digunakan beberapa metode pengujian data kuisioner untuk mendapatkan data yang valid secara statistik.

\subsubsection{Uji Validitas}

Uji Validitas berfungsi untuk mengukur valid tidaknya sebuah kuisioner dimana kuisioner dikatakan valid jika pertanyaan dalam kuisioner mampu mengungkapkan suatu hal yang akan diukur dalam kuisioner tersebut. Validitas digunakan untuk mennentukan seberapa baik suatu alat ukur yang dikembangkan mampu mengukur instrumen. Dengan uji ini diharapkan diperolehnya bukti mengenai kualitas item item alat ukur yang digunakan dan memberikan informasi perbaikan pada item pertanyaan.

Alat ukur yang berdasarkan pada teori tertentu masih harus dilakukan uji kebenarannya secara empiris. Dari pengujian data empiris inilah diharapkan diperolehnya bukti mengenai kualitas item item alat ukur yang digunakan (Kharisma, 2015)

\subsubsection{Uji Reliabilitas}

Uji reliabilitas merupakan tingkat kestabilan suatu alat pengukur dalam mengukur suatu kejadian. Kuisioner dikatakan reliabel jika jawaban terhadap pertanyaan konsisten. Semakin tinggi nilai relaiabilitas alat pengukur maka semakin stabil pula alat pengukuran tersebut begitu juga sebaliknya semakin rendahnya reliabilitas akan menunjukkan ketidakandalan alat ukur. Nilai koefisien ini bekisar antara 0,00 sampai dengan 1,00 .

Metode yang umum digunakan dengan aturan nilai Alpha Cronbach. Koefisien Alpha Cronbach $(\alpha)$ dapat dihitung dengan persamaan sebagai berikut :

$$
\alpha=\frac{k r}{1+(k-1) r}
$$

$$
\begin{array}{ll}
\alpha & =\text { koefisien reliabilitas Cronbach Alpha } \\
k & =\text { jumlah item } \\
r & =\text { korelasi item rata rata }
\end{array}
$$

\section{Kerangka Konseptual}




\subsection{Servqual}

Pengukuran yang digunakan dalam pengukuan servqual terdiri dari dua bagian yaitu (1) bagian harapan yang memuat pertanyaan yang dapat menghimpun dengan pasti harapan umum dari pelanggan atau konsumen terhadap jasa transportasi Go-Ride dan (2) Bagian pengalaman yang berisi pertanyaan untuk mengukur bagaimana persepsi dan pengalaman konsumen saat ini dari jasa transportasi Go-Ride berdasarkan kategori yang ditentukan. Secara umum nilai ini merupakan gap dari Ekspektasi dan Persepsi pelanggan. Nilai Service quality setiap pertanyaan masing masing pelanggan dapat dihitung berdasarkan rumus berikut (Tjiptono 2005:275)

Skor Servqual $=$ Skor Persepsi - Skor Harapan

Pengukuran hasil survey dapat dilakukan dengan membandingkan rata rata harapan dengan persepsi pada setiap instrumen sehingga akan didapatkan Gap/kesenjangan.

\subsection{Kepuasan Pelanggan (Customer Satisfaction)}

Menurut (Kotler, 2014) Kepuasan pelanggan merupakan perasaan senang atau kecewa yang muncul setelah membandingkan kinerja (hasil) produk yang dipikirkan terhadap kinerja (atau hasil) yang diharapkan. Dari definisi tersebut kepuasan pelanggan dapat dirasakan setelah pelanggan atau konsumen membandingkan pengalaman mereka dalam melakukan pembelian barang/jasa dari penyedia jasa atau penyedia barang dengan harapan dari pelanggan itu sendiri.

\subsection{Loyalitas Pelanggan (Customer Loyalty)}

Menurut (Griffin dalam Kharisma, 2015) loyalitas pelanggan didefinisikan sebagai pembelian non-random yang diekspresikan sepanjang waktu dengan melakukan serangkaian pengambilan keputusan dimana loyalitas pelanggan ditunjukkan dengan suatu perilaku pembelian rutin oleh pengambil keputusan (pelanggan). Dari definisi tersebut dapat disimpulkan bahwa loyalitas pelanggan tidak sebatas pada perilaku berulang tetapi sikap positif terhadap penyedia jasa.

Karakteristik loyalitas pelanggan meliputi (1) Melakukan pembelian secara teratur (2) Membeli di luar lini produk/jasa (3) Mereferensikan kepada orang lain dan (4) Menunjukkan kekebalan daya tarik pesaing atau tidak mudah terpengaruh oleh tarikan persaingan perusahaan sejenis lainnya.

\subsection{Intention to Repurchase}

Menurut (Hellier, 2003) Repurchase Intention merupakan keputusan terencana seseorang untuk melakukan pembelian kembali atas jasa tertentu dengan mempertimbangkan situasi yang terjadi dan tingkat kesukaan.

\subsection{Kerangka Pemikiran dan Hipotesis}

Dalam penelitian yang dilakukan oleh (Catherine, et al, 2019) menjelaskan bahawa ada pengaruh antara Servqual dan Customer Satisfaction dalam studi kasus kualitas layanan bandara terhadap penumpang dan niat perilaku termasuk penggunaan kembali bandara. Berdasarkan penelitian tersebut, maka disusun hipotesis sesuai dengan Gambar 1.

H1 : Servqual mempengaruhi Kepuasan pelanggan (customer satisfaction)

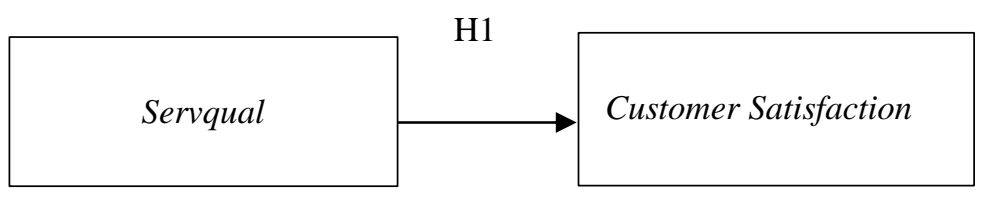

Gambar 1 Kerangka konseptual H1

Penelitian yang dilakuan oleh (Leila Agha, et al , 2017) menjelaskan bahwa adanya pengaruh antara kepuasan pelanggan (customer satisfaction) dan loyalitas pelanggan (customer loyalty). Berdasarkan penelitian tersebut maka disusun hipotesis seperti Gambar 2: 
$\mathrm{H} 2$ : Kepuasan pelanggan berpengaruh terhadap loyalitas pelanggan

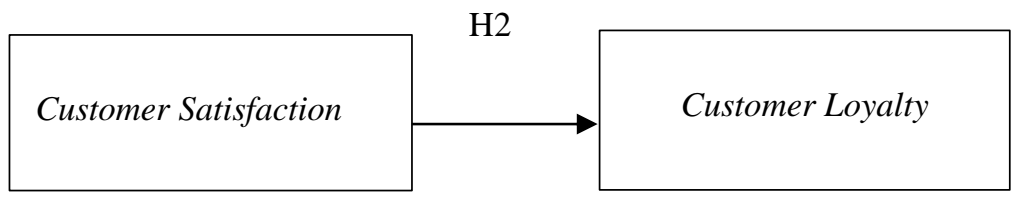

\section{Gambar 2 Kerangka Konseptual H2}

Penelitian yang dilakukan oleh (Mateja, et, al, 2015) menjelaskan bahwa kepuasan pelanggan (customer satisfcation) berpengaruh terhadap loyalitas pelanggan (customer loyalty) studi kasus pada perusahaan pesawat terbang. Selain peneltiian tersebut juga terdapat peneltiian (Chao Wen, 2015) juga menjelaskan bahawa kepuasan pelanggan (customer satisfcation) berpengaruh terhadap loyalitas pelanggan (customer loyalty). Maka disusun hipotesis seperti pada Gambar 3:

H3 : Customer Satisfaction mempengaruhi Intention to repurchase

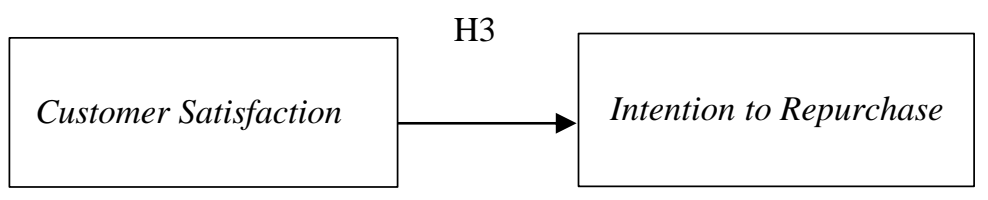

Gambar 3 Kerangka Konseptual H3

Penelitian yang dilakukan oleh (Eesan Ahmad, et, al , 2016) menjelaskan bahwa loyalitas pelanggan berpengaruh terhadap intention to repurchase dalam kasus sebuah brand. Dari penelitian tersebut maka disusun hipotesis seperti pada Gambar 4 :

$\mathrm{H} 4$ : Customer loyalty mempengaruhi intention to repurchase

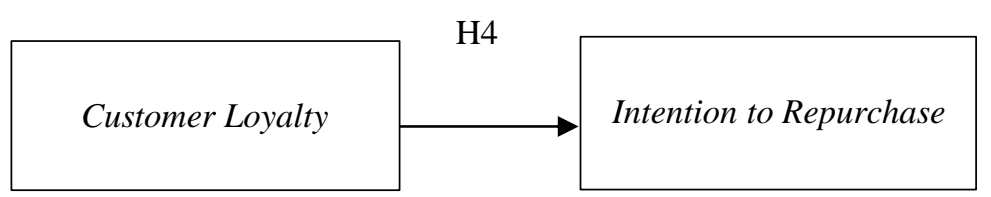

Gambar 4 Kerangka Konseptual H4

Dari instrumen seperti yang dijelaskan maka kerangka konseptual yang meliputi dimensi Servqual, Customer Satisfaction, Customer Loyalty dan Intention to repurchase dalam penelitian ini dapat digambarkan seperti pada Gambar 5 


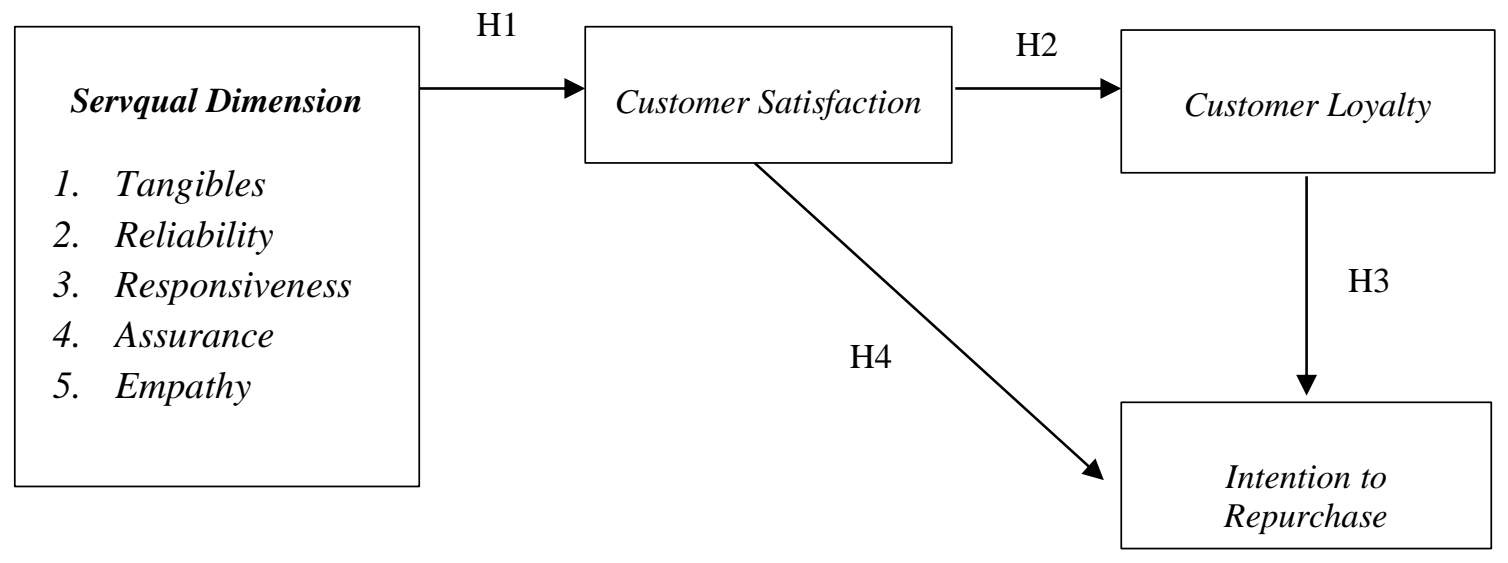

\section{Gambar 5 Kerangka Konseptual Kepuasan Pelanggan}

\section{Metodologi Penelitian}

Metode penltiian ini mendefinisikan bagaimana kerangka konseptual dibentuk dan bagaimana penelitian dilakukan termasuk proses dan pendekatann penelitian adapun proses penelitian ini dapat dilihat pada Gambar 6.

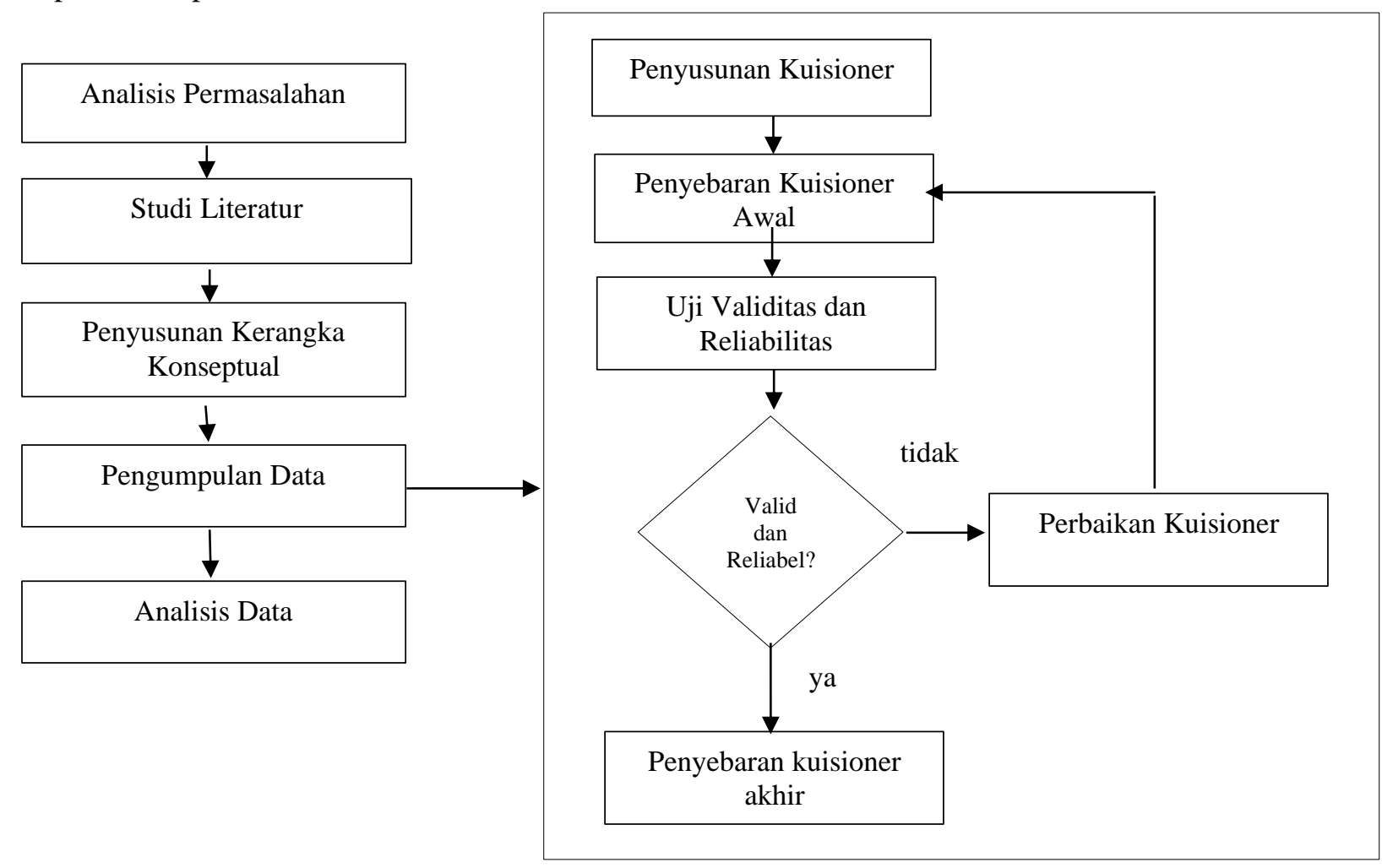

\section{Gambar 6 Metode Peneltian}

Peneltian ini menggunakan pendekatan kuantitatif dimana pengumpulan data dilakukan dengan cara survei yang didistribusikan secara online melalui berbagai media seperti whatsapp dan jejaring sosial lainnya. Survey online dipilih karena memiliki jangkauan luas, relatif tanpa biaya 
dan dapat dengan mudah disebarkan. Dalam kuisioner terdapat data umum responden, pertanyaan untuk servqual, kepuasan pelanggan, loyalitas pelanggan dan keinginan untuk menggunakan kembali jasa tersebut.

\section{Kesimpulan}

Penelitian ini secara rinci memberikan tinjauan literatur secara rinci mengenai kualitas layanan, kepuasan pelanggan, loyalitas pelanggan dan keinginan untuk menggunakan jasa tersebut khususnya dalam bidang jasa transportasi online Go-Ride. Kerangka konseptual telah diusulkan untuk mengukur kualitas layanan, kepuasan pelanggan dan loyalitas pelanggan. Penelitian ini dapat membantu para pemangku kepentingan dan pelanggan dalam mengukur kualitas layanan dan mengatur strategi dan pengambilan keputusan bagaimana cara meningkatkan kualitas layanan pelanggan khususnya pengguna jasa transportasi online Go-Ride. Dalam hal ini dari pihak penyedia jasa transportasi juga dapat membagi pelanggan dalam berbagai kategori sehingga tau bagaimana memposisikan di masa yang akan datang yang dapat dibandingkan kualitas layanan dengan pesaing penyedia jasa transportasi online tersebut.

\section{Referensi}

Ahmad. H. Zeeshan, Jun. Meng, Khan. Imran, Abdullah Muhammad, Ghauri. Ahmad Tauqir. 2016. Examining Mediating Role of Customer Loyalty for Influence of Brand Related Attributes on Customer Repurchase Intention. Journal of Northes Agricultural University.

Hellier. K. Phillip, Geursen. M. Gus, Carr. Rodney, Rickard. A. John. 2003. Customer Repurchase Intention : A General Structural Equation Model. European Journal of Marketing. Vol 37 (11/12) pages 1762-1800.

Kasiri, Leila Agha \& Guan Cheng, Kenny Teoh \& Sambasivan, Murali \& Sidin, Samsinar Md., 2017. Integration of standardization and customization : Impact on service quality, customer satisfaction, and loyalty. Journal of Retailing and Consumer Services, Elsevier, Vol.35 (C), pages 91-97.

Kos Koklic, Mateja \& Kukar-Kinney, Monika \& Vegelj, Spela, 2017. "An investigation of customer satisfaction with low-cost and full-service airline companies," Journal of Business Research, Elsevier, vol. 80(C), pages 188-196.

Kotler, P., K. L. Keller. 2006. Manajemen Pemasaran, Ed12. Jilid 2. Penerbit PT. Indeks: Jakarta

Kharisma. 2015, Analisis Kepuasan Pelanggan Situs Online Shop Jenis B2C (Business To Consumer) dan Dampaknya pada Tingkat Loyalitas dengan menggunakan Metode EServqual. Tugas Akhir. Program Studi Manajemen Rekayasa Industri. Institut Teknologi Bandung.

Kunaefi. 2002, Aplikasi Metode Servqual dalam Mengukur Tingkat Kepuasan Pelanggan PLN Segmen Rumah Tangga. Tugas Akhir. Program Studi Teknik Industri. Institut Teknologi Bandung.

Laudon, Kenneth C., and Jane P. Laudon. 2011. Essentials of Business Information Systems 7th Edition. New Jersey: Pearson Educational Edition.

Maholtra, N. K., and David F. Birks. 2007, Marketing Research : an Applied Approach. Essex: Pearson Education Lrd.

Panchapakesan, Padma., Chandrasekharan, Rajendran and L.Prakash, Sai. 2009, A Conceptual Framework of Services Quality I healthcare; Perspectives of Indian patients and their Attendants: Benchmarking An International Journal. Volume 16 No.2 pages 1463-5771.

Parasuraman, Parsu A. Zeithaml, A. Valarie, Berry, L.Leonard. 1985. A Conceptual Model of Services Quality and its Implication for Future Research. Joirnal of Marketing. Vol.49 pages $41-50$

Prentice. Catherine, Kadan. Mariam. 2019, The role of airport service quality in airport and destination choice. Journal of Retailing and Customer Services. Volume 47 (C) pages 4048 
Shilvia L.Br. Silalahi, Putu W. Handayani, Qorib Munajat. 2017, Services Quality Analysis for Online Transportation Services : Case Study of Go-JEK: Procedia Computer Science. Volume 124 No.2 pages 487-495.

Tjiptono, Fandy, \& Gregorius Chandra. 2011, Service Quality \& Satisfaction. Yogyakarta. ANDI.

Wen. Chao, Prybutok. V.R, Xu, Chenyan. 2011. An Integrated Model for Customer Online Repurchase Intention. Journal of Computer Information Systems. Volume 52 (1) pages 14-23.

Zeithaml, V.A., A. Parasuraman, and Arvind Maholtra. 2002. Service Quality Delivery Through Web Sites: A Critical Review of Extant Knowledge. Journal of the Academy of Marketing Science. Volume 30, No. 4 pages 362-375.

Zeithaml, V.A., A. Parasuraman, and Arvind Maholtra. 2005. E-S-QUAL: A Multiple-Item Scale for Assessing Electronic Service Quality : Journal of Service research. Volume 7, No.3 pages 213-233. 